believe that a meeting here would be of great value for British geodesy; but I told the conference that I had no power to give an invitation, which must come from the Government. I can only now repeat the expression of the hope that the conference may meet in this country in rgog.

G. H. Darwin.

THE FIRST "MANNED" FLYING MACHINE.

CTOBER 23 of the present year will be remembered as a red-letter day in the history of flying machines, for it was on that day that the first flying machine, constructed on the "heavier than air", principle, successfully raised itself and its driver from the ground several feet, and transported itself by means of its own power over a distance of eighty yards.

In this his first successful flight with this machine. M. Santos Dumont is to be sincerely congratulated, for he has accomplished a performance which many workers in different parts of the world have been striving after for many years past and failed. M. Santos Dumont's machine is built on the aëroplane principle, and mounted on two wheels. It is fitted with an eight-cylinder, 60 h.p. motor weighing about I7o 1b., and drives an aluminium fan, which makes 1000 to 1500 revolutions a minute. The motor is the work of the Adams Manufacturing Company, England. With its driver the machine weighs about $750 \mathrm{lb}$.

The aeroplane is shaped like a large $\mathrm{T}$ placed horizontally. The short arms of the $T$ are slightly inclined upwards, and are each composed of three compartments, like three box-kites tied together side by side. At the base of the $T$ is a large compartment, also like a box-kite, and by manipulating this about a horizontal axis the upper and lower surfaces act as a powerful rudder. This rudder arrangement is at the front end of the aeroplane, and the operator stands on a platform midway between, and nearly on a level with, the lower surfaces of the two main inclined arms. The driving fan is situated at the rear of the machine, just behind the operator, at the junction of the two main inclined arms.

Now that success has rewarded this daring investigator, it is of interest to take a cursory glance at the steps which ultimately led the way to success.

One naturally, in the first instance, calls to mind the very interesting experiments carried out in 1893 by Herr Otto Lilienthal near Berlin (NATure, vol. xlix., p. $1_{57}$ ), because Santos Dumont's aëroplane is, generally speaking, somewhat after the style of the gliding machines used by him. Lilienthal's experiments were confined to trying to learn soaring, and he employed slightly curved wings having a surface of about $I_{5}$ square metres. With these inclined planes, and eventually vertical and horizontal rudders, he started from the top of a hill, and after a few steps forward jumped into the air and glided sometimes 250 metres. Lilienthal depended for the success of his apparatus on himself, trusting to his instinct to be able to keep his balance by making the necessary compensating adjustments by moving his own centre of gravity. In later experiments he employed some mechanical aid to assist him in sustaining himself longer in the air. This consisted of a small machine driven by compressed carbonic acid gas, and operating a series of feather-like sails which were capable of flapping. He found that occasional flapping of these wings helped him to cover longer distances.

In 1895 he adopted a new principle, and instead of using one large framework, employed two smaller ones, placed parallel one above the other; this method he found distinctly advantageous (NArure, vol. liii., p. 300).

About this time Lilienthal's soaring experiments began to be taken up both in this country and in America. Mr. Percy S. Pilcher in England gained considerable experience both in the making and in the handling of these aerroplanes (NATuRE, vol. lvi., p. 344). Unfortunately, as in the case of Herr Lilienthal, an accident during his experiments resulted in his death. Pilcher, however, was quite aware of the importance of using some motive power, and some time before his death proposed to employ, and actually began to make, a small and light engine, indicating about 4 h.p., to drive a fan, this being considered by him as more than sufficient for flights of moderate length. With this advance it was hoped that much greater distances could be covered, and a nearer approximation to a flying machine attained.

There is little doubt that if Pilcher had been spared he would soon have constructed and made use of the latest and lightest form of motor, and probably been led to use the double-decked form of aëroplane adopted by Santos Dumont.

By embodying the best ideas of his predecessors and using his own ingenuity to make the aëroplane a practical flying machine, Santos Dumont has advanced the science of aëronautics a very considerable step. The petrol motor has no doubt helped greatly in facilitating this progress, since highpowered engines of comparatively very light weight can be constructed.

In this pioneer work of navigating the air the work of Hiram Maxim and S. P. Langley must not be forgotten. Maxim made numerous attempts to drive his flying machine at such a speed that it would be lifted off the rails on which it ran, but on no occasion could it be said that this was successfully accomplished. Further, it was not known whether it would capsize or not if it was set free. Langley, on the other hand, was undoubtedly the first to demonstrate that a machine heavier than air could be made to travel in the air driven by its own power. The machines he made and launched were all " unmanned," but nevertheless much valuable information was accumulated.

This the latest achievement of Santos Dumont will no doubt give a fresh impetus to the problem of flight, and those who have the money and time have now before them a successful aëroplane that can serve as a starting point.

\section{THE UNIVERSITY MOVEMENT IN WESTERN AUSTRALIA.}

A MEETING in support of the movement for founding a university in Western Australia was held on September 7 at Perth, Western Australia. The chair was taken by Dr. J. W. Hackett, and the principal speakers included the chairman, the Right Rev. Dr. Riley, Anglican Bishop of Perth, Dr. Hill, master of Downing College, Cambridge, who is at present lecturing in Western Australia, and the Speaker of the Legislative Assembly, Mr. Quinlan. In I904, during the Premiership of Mr. Walter James, 4000 acres of land in the vicinity of Perth were set apart by the Legislative Assembly as a permanent endowment for the University of Western Australia when it should come to be formed. The present income from this endowment is practically nil, but its future value is likely to be considerable.

Dr. Hackett in his remarks explained the general

NO. I932, VOL. 75] 
vieiv that the university should be to enable the youth of the country to develop their faculties to their full capacity, and to permit them to compete on even terms in the practical business of life with those outside as well as inside Australia. Dr. Hill, in a valuablo contribution to the discussion, advocated the utilisation of existing institutions, the training college for teachers, the magnificent observatory, the museum, zoological gardens, law courts, and hospital, for the teaching purposes of the university, and suggested thai many of the gentlemen holding Government appointments, the geologist, electrician, bacteriologist, \&c., were eminently fitted to occupy university chairs in addition to their official duties. They did not require a palace for a start, but the men. In these days of change a great stone building was a disadvantage. His idea was to forget finance, and to coordinate the existing material. Ultimately a resolution in favour of the establishment of a university was carried with practical unanimity.

At present the higher education of Western Australia is in the hands of the University of Adelaide, which conducts the examinations and gives courses of extension lectures, and this system has worked well in the past, but naturally is only provisional. In addition, the Gilchrist trustees, through Dr. R. D. Roberts, of the London University Extension Board, have for the past three years contributed to the expense of sending an annual lecturer from this country to give a course of lectures in some branch of science. These lectures are eagerly attended, and now form quite a feature in the intellectual life of the State, periodically stimulating the movement in favour of an independent university. Audiences of from I000 to I 500 are sometimes drawn. It is difficult to say whether the lecturer or his audience derive the greater benefit. Certainly a trip round the world with a course of lectures, taking one over a large part of a new continent, among the goldfields of Kalgurli, the jarrah and karri forests of the south-west, the orchards and vineyards of Armadale, is an experience fitted to make a lecturer return to his homely desk with " renewed vinegar."

The present writer recalls many a strange impression from his lecturing experience in Western Australia; a wine neither a hock, a claret, nor a madeira, something of each, but better than all; a third-class sleeping carriage on a narrow-gauge, single-line railway, not yet to be found on our boasted Scotch expresses; gold in sight in the wall-face of one working not yet worked, estimated of the value of half a million sterling; a water scheme for supplying the mines, pumping a million and a half gallons daily over a watershed of $\mathrm{I} 500$ feet a distance of 300 miles, in which the water spends six weeks in the pipes before reaching its destination; a camel, the only need of which in the desert is a weekly drink of water costing, maybe, 3os.; a criticism of the last night's lecture scribbled in pencil at the bottom of one mine, and delivered to the lecturer in the next without coming nearer the surface than rzoo feet; a rabbit which survived two summers of drought without water; and a clergyman who took for his text "Radium."

In wishing the university movement well in Western Australia, one may express the hope that it will still continue its policy of inviting outside lecturers to come and learn as well as to teach, and that many professors without portfolios may be induced to visit its shores in the future, to carry back with them an idea of a developing outside world which in the cloistered seclusion of a university is in danger of slipping from the memory.

NO. I932, VOL. 75$]$

F. S.

\section{NOTES.}

THE following is a list of fellows who have been recommended by the president and council of the Royal Society for election into the council for the ensuing year :-president, Lord Rayleigh; treasurey, Mr. A. B. Kempe; secretaries, Prof. J. Larmor, Sir Archibald Geikie; foreign secretary, Mr. Francis Darwin; other members of the council (the fellows whose names are printed in italics are not members of the existing council), Lord Avebury, Sir Benjamin Baker, K.C.B., Dr. H. F. Baker, Prof. J. Norman Collie, Prof. Wyndham R. Dunstan, Prof. David Ferrier, Prof. Sydney J. Hickson, Sir William Huggins, K.C.B., Prof. E. Ray Lankester, Mr. H. F. Newall, Dr. Alexander Scott, Prof. A. C. Seward, Prof. W. J. Sollas, Prof. E. H. Starling, Prof. Silvanus P. Thompson, and Dr. A. D. Waller.

THE Royal Society's medals have this year been adjudicated by the president and council as follows:--the Copley medal to Prof. Elias Metchnikoff, for the importance of his work in zoology and in pathology; the Rumford medal to Prof. Hugh Longbourne Callendar, for his experimental work on heat; a Royal medal to Prof. Alfred George Greenhill, for his contributions to mathematics, especially the elliptic functions and their applications; a Royal medal to Dr. Dukinfield Henry Scott, for his investigations and discoveries in connection with the structure and relationships of fossil plants; the Davy medal to Prof. Rudolf Fittig, for his investigations in chemistry, and especially for his work in lactones and acids; the Darwin medal to Prof. Hugh de Vries, on the ground of the significance and extent of his experimental investigations in heredity and variation; the Hughes medal to Mrs. W. E. Ayrton, for her experimental investigations on the electric arc, and also upon sand ripples. The King has approved of the award of the Royal medals. The medals will, as usual, be presented at the anniversary meeting on St. Andrew's Day (November 30). The society will dine together at the Whitehall Rooms on the evening of the same day.

Two events during the past few days have shown that men of science recognise the ability of women to originate and carry out scientific research and inspire others with their spirit. One is that on Thursday' last the, Royal Society awarded the Hughes medal to Mrs. W. E. Ayrton, for her experimental investigations on the electric arc and also upon sand ripples; and the other event is the first lecture delivered at the Sorbonne on Monday by Mme. Curie, who has succeeded the late Prof. Curie in the chair of general physics of the University of Paris. Both Mrs. Ayrton and Mme. Curie originated and carried out their scientific investigations unaided, and the tacit acknowledgment just made of their creative capacityessential to work of this kind-is interesting and signifcant. Though some of Mrs. Ayrton's experiments on the electric arc were made in the laboratories under Prof. Ayrton's charge at the Central Technical College, it was to her alone that the conception and carrying out of the experiments were due, as well as the original speculations deduced from the results. The Royal Society, by placing Mrs. Ayrton's name alone, and not bracketed with that of a man, in the list of medallists for this year has manifested its recognition of individual work by a woman. The Davy medal was awarded by the society in 1903 to Prof. Curie and Mme. Curie jointly, for their researches on radium, though the published work on the subject shows that the discovery of radium was due to $M$ me, 